V. Goliuk,

$\mathrm{PhD}$ in Economics, associate professor, associate professor of management department, National Technical University of Ukraine "Igor Sikorsky Kyiv Polytechnic Institute"

ORCID ID: 0000-0002-8050-4158

\title{
THE EFFECT OF POPULATION DYNAMICS ON GDP GROWTH IN INDIA
}

\author{
В. Я. Голюк, \\ к. е. н., Аоцент, доцент кафедри менеджменту, Національний технічний \\ університет України "Київський політехнічний інститут імені Іторя Сікорського"
}

\section{ВПЛИВ АИНАМІКИ ОБСЯГІВ НАСЕАЕННЯ НА ЗРОСТАННЯ ВВП У ІНАІЇ}

The aim of the paper is to study the impact of population dynamics on gross domestic product GDPgrowth in India. During last two decades India has been showing phenomenal economic development. One of its main reasons is economic and social policy has been provided by government. Since 1990-s India has deregulated several industries, has privatized many state-owned enterprises, and contributed to foreign direct investment. The Indian middle class, that is almost a quarter of its total population amount, has been driving economic growth in India. High level of education and English-speaking population in urban areas attract foreign investments and provide fertile ground for an intensive development of the country's high-technology sector.

Economic views on the relationship of population and economic growth are divided into two areas: one that argues that population growth contributes to the nation's economy by stimulating economic growth and development, and the other argues that population growth may be detrimental to the nation's economy. Results of this research are consistent with the first theory.

The study revealed that in 1961-2018 population dynamics (ages 15-64) was associated with GDP growth (per capita) in India positively, and strength of the relationship was moderate that means there are many factors push economic growth in India and population dynamics is only one of them. The Augmented Dickey-Fuller test has been used to check population and GDP growth series to identify if they are stationary and can be used for Granger causality test. It has shown that population and GDP growth series are stationary and Granger causality test can be performed to identify the direction of causality for these series. Granger causality test has shown that population dynamics Granger causes GDP growth in India. Correlation coefficient R=0,54 demonstrates that population dynamics has been playing important but not a single role in stimulating economic development in India. Therefore population dynamics can be effective driver of economic development of the state being combined with other policy measures.

Аослідження присвячено впливу динаміки населення на економічний розвиток Індї. Протягом останніх двох, десятиліть Індія демонструє феноменальний економічний розвиток. ОАнією з його головних причин є економічна та соціальна політика, що поводилася урядом. Починаючи з 1990-х років, Індія дерегулювала кілька галузей промисловості, приватизувала багато,державних підприемств та сформувала сприятливі умови Аля прямих іноземних інвестицій. Індійський середній кАас, що становить майже чверть ї̈ загальної кількості населення, Сприяе економічному зростанню. Високий рівень освіти та англомовне населення у міських районах приваблюють іноземні інвестиції та забезпечують сприятливе підгрунтя дАя інтенсивного розвитку сектору високих технологій в країні.

Позиції економістів щодо взаємозв'язкунаселення та економічного зростання розділяються загалом на два напрями: той, який стверджує, що збільшення чисельності населення сприяє економіці нації, стимулюючи економічне зростання та розвиток, а інший стверджує, що збільшення чисельності населення може згубно впливати на економіку нації. Результати цьогодослідження підтримують перший напрям.

Аослідження продемонструвало, що в 1961-2018 роках динаміка населення (у віці 15-64 років) в Індії було позитивно пов'язано зі зростанням ВВП (на душу населення), а Ступінь цього зв'язку був по- 
мірний, що означає, що в Індї існує багато факторів, які стимулюють економічне зростання, а динаміка чисельності населення є Аише одним з них. У рамках,дослідження дАя перевірки Статистичних рядів чисельності населення та зростання ВВП було використано,доповнений тест,Діккі-ФулАера (АDF), щоб визначити, чи є вони стаціонарними та чи можуть бути використані дАя тесту причинності Грейнджера. АDF продемонстрував, що ряди чисельності населення та зростання ВВП є Стаціонарними, і тест причинності Грейнджера може бути проведений Аля виявлення напрямку причинності їх зв'язку. Тест причинності Грейнджера продемонстрував, щодинаміка населення Коефіцієнт кореляції $R=0,54$ демонструє, що, динаміка населення відіграє важливу, алена одноосібну роль У Стимулюванні економічного розвитку Індії. Таким чином позитивна, динаміка чисельності населення може бути ефективним рушієм економічного розвиткУ, Аржави, поєАнуючись з іншими заходами економічної політики.

Key words: population, economic growth, gross domestic product, correlation, causality, India.

Ключові слова: населення, економічне зростання, валовий внутрішній продукт, корелячія, причинно-наслідкові зи' язки, Індія.

\section{INTRODUCTION}

The relationship between population dynamics and economic growth is controversial. Population structure and dynamics can both affect and be affected by economic development of a country. Fast population growth in lowincome countries may slow down their development while slow population growth in high-income countries may cause economic and social problems. In general, growing economies need growing populations, increasing the supply of both workers and consumers, although the precise nature of this relationship is of course complex and variable. But very strong population growth helps to explain why GDP per capita, and therefore living standards, continue to stagnate - although it may be that aggregate GDP growth would have been even lower without population growth. [1].

India is one of modern economic miracles demonstrating high economic growth over past twenty years. In the first three decades after independence in 1947, the economy was known for its steady rate of growth of 3,5 percent [3]. After three postindependence decades of meager progress, the country's economy grew at 6 percent a year from 1980 to 2002 and at 7.5 percent a year from 2002 to 2006 - making it one of the world's best-performing economies for a quarter century [4]. Since then its growth annual rate repeatedly reached $6 \%$ (and once even $7 \%$ ) per year [2] (see Fig. 1). Now India is the world's fourth-largest economy [5]. It is one of the world's fastest-growing economiesaccounting for about 15 percent of global growth [6]. Socalled Mumbai consensus has become exemplary model for developing countries looking for effective measures able to trigger economic growth. Although its economic growth has been slowing down in recent years, Indian economic growth model being focused on its domestic market could be a valuable lesson for other countries Ukraine included.

\section{ANALYSIS OF RECENT RESEARCHES}

\section{AND PAPERS}

The paper is focused on the case of economic development in India. Number of researches $[7 ; 4 ; 8 ; 9 ; 1]$ prove that economic development in India related to its focus on domestic market, growing consumption and middle class Indians. The relationship between population dynamics and economic development has long been of interest by researches across the world. Economists are torn between two theories; one that states population increase and growth help a nation's economy by stimulating economic growth and development and another that bases on Robert Malthus' findings. Malthus states that population increase is detrimental to a nation's economy due to a variety of problems caused by the growth [10].
Number of studies contribute to the first theory, stating that in certain circumstances population growth can push economic development of the state. Andrew Gamble states that the remarkable success of Western economies in the past 200 years is associated with strong population growth [11]. Thomas Piketty [12] indicates that "...growth always includes a purely demographic component and a purely economic component". Analysts Atanda A.A., Aminu S.B. and Alimi O.Y. [13] investigated the relationship between population growth and per capita income in a set of developing and developed countries. The trend analysis revealed that fertility rate, crude death rate, birth rate, mortality rate, and life expectancy are the major determinants of rapid population growth rate, while youth dependency ratio of young people below age 15 has also been attributed as one of the leading causes of population growth and growth threat in developing countries [13]. Yanwei Zhang and Hualin Xie performed investigation of the relationship in China and the results show that there is a long-term equilibrium relationship among urban expansion, economic development and population growth [14].

\section{SETTING OBJECTIVES}

The influence of population dynamics on economic growth is controversial. Study is performed to analyze the effect of population dynamics on GDP growth in India, to indicate the factors that have been driving Indian economic boom.

\section{METHODOLOGY}

In the study the Augmented Dickey-Fuller (ADF) test has been used to identify stationary series, the Pearson's correlation test has been used to analyze the relationship between population dynamics (ages 15-64) and GDP growth (per capita) in India. Granger causality test has been used to study the causation in these associations. Calculations have been performed by means of Microsoft Excel and Eviews. Data has been collected from World Data Atlas "Knoema" for the period 1961-2018.

\section{RESEARCH RESULTS}

A variety of factors play into the models that depict India's growing economy. Population dynamics is one of them. India has a mixed economy. Half of India's workers rely on agriculture. One-third of its workers are employed by the services industry, which contributes two-thirds of India's output. The productivity of this segment is made possible by India's shift toward a market economy. Since the $1990 \mathrm{~s}$, India has deregulated several industries, has privatized many state-owned enterprises, and opened doors 


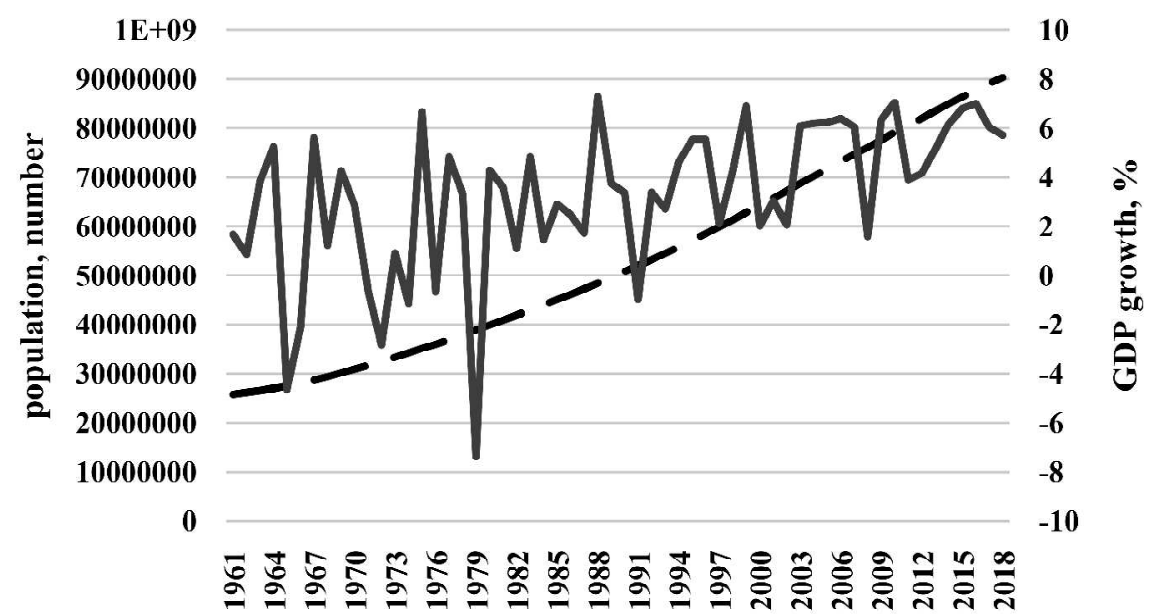

- Population ages 15-64, total — GDP per capita growth (annual \%)

Fig. 1. Population and GDP growth dynamics in India

Source: developed by author on the basis of [2].

to foreign direct investments [5]. English is one of India's official subsidiary languages. This, combined with the high level of education and comparatively low wages, attracts U.S. technology and call centers to India. India has a young and growing youth population, and about two-thirds of the total population is of working age (between 15 and 64) [6]. The Indian middle class is almost 250 million people - a quarter of its total population amount. K. Amadeo in her research paper states that Indian middle class will continue to drive India's consumer spending and economic growth [5]. Rohan Kothare has also stated that India has become one of the world's fastest growing economies primarily due to the rise in population growth creating a positive effect on its long run economic growth. Due to the rising population a large labor force is thus created. Through Indian fiscal policies, India was able to spend money on education to instruct the youth and adults, in order to help them play a productive role in India's economy [13]. Indian experience shows that the promise of a good outcome is greater when countries not only support foreign direct investments but also are able to invest in themselves.

Results of this research are consistent with previous studies results. Correlation analysis of the relationship between population dynamics and GDP growth in India has brought the following results (see table 1). Correlation coefficient value reaches the highest degree if $\mathrm{lad}=0$ and decreases as lag increases. The study revealed that in $1961-$ 2018 population dynamics (ages 15-64) was associated with GDP growth (per capita) in India positively that means population growth is accompanied with GDP per capita growth. Association strength in all cases studied is moderate that means there are many factors push economic growth in India and population dynamics is only one of them.
Granger causality test can prove if GDP growth is followed by population dynamics or vice versa, but it provides reliable results if only series are stationary. In the research the Augmented Dickey-Fuller (ADF) test has been used to check population and GDP grow th series to identify if they are stationary. The Augmented Dickey Fuller Test $(\mathrm{ADF})$ is unit root test for stationarity. Unit roots can cause unpredictable results in time series analysis that's why the analysis has been performed to be sure that the null hypothesis has been rejected (the null hypothesis for this test is that there is a unit root). According to ADF methodology $p$-value of less than $5 \%$ means that there is a unit root. Calculations results of ADF-test are following: $p$ value $=6$ that allows to assume that there no unit root. To make sure t-statistic has been compared with a tabulated critical value: tcritical $=2.89$, tcalculated $=8.7172$, therefore tcritical $<$ tcalculated. This result means that population and GDP growth series are stationary and Granger causality test can be performed to identify the causality direction of these series.

Table 1. Results of correlation analysis of relationship between population dynamics and GDP growth in India

\begin{tabular}{|l|l|c|l|}
\hline \multirow{2}{*}{ Lag } & \multirow{2}{*}{$\begin{array}{c}\text { Correlation } \\
\text { coefficient } \\
\text { value }\end{array}$} & \multicolumn{2}{|c|}{$\begin{array}{c}\text { Interpretation of correlation coefficient } \\
\text { value }\end{array}$} \\
\cline { 3 - 4 } & & Interval & Association strength \\
\hline 0 & 0.5411 & $0.5<0.5411<0.7$ & moderate \\
\hline 1 year & 0.534358 & $0.5<0.534358<0.7$ & moderate \\
\hline 2 years & 0.523961 & $0.5<0.523961<0.7$ & moderate \\
\hline 3 years & 0.504595 & $0.5<0.504595<0.7$ & moderate \\
\hline
\end{tabular}

Source: calculations have been performed by the author on the basis of [2].

Table 2. Pairwise Granger Causality Tests

\begin{tabular}{|l|l|l|l|l|}
\hline $\begin{array}{c}\text { Number } \\
\text { of lags }\end{array}$ & $\begin{array}{c}\text { Number of } \\
\text { observations }\end{array}$ & \multicolumn{1}{|c|}{ Null Hypothesis } & F-statistic & Probability \\
\hline 1 year & 57 & $\begin{array}{l}\text { PD does not Granger } \\
\text { cause GDP }\end{array}$ & 21.7016 & $2 \mathrm{E}-05$ \\
\cline { 3 - 5 } & $\begin{array}{l}\text { GDP does not } \\
\text { Granger cause PD }\end{array}$ & 0.03366 & 0.8551 \\
\hline 2 year & 56 & $\begin{array}{l}\text { PD does not Granger } \\
\text { cause GDP }\end{array}$ & 11.8280 & $6 . \mathrm{E}-05$ \\
\hline & $\begin{array}{l}\text { GDP does not } \\
\text { Granger cause PD }\end{array}$ & 0.25526 & 0.7757 \\
\hline 3 year & 55 & $\begin{array}{l}\text { PD does not Granger } \\
\text { cause GDP }\end{array}$ & 6.8167 & 0.0006 \\
\cline { 3 - 5 } & $\begin{array}{l}\text { GDP does not } \\
\text { Granger cause PD }\end{array}$ & 0.39686 & 0.7558 \\
\hline
\end{tabular}

Source: calculations have been performed by the author on the basis of [2]. 
Granger causality test for the period 1961-2018 revealed that population dynamics (PD) Granger causes GDP growth. But the bigger the number of lags the smaller magnitude of F-statistics becomes and the magnitude of probability also grows (see Table 1 ). In the table 2 the results show that first null hypothesis can be rejected therefore population dynamics (PD) Granger causes GDP growth. Another null hypothesis cannot be rejected. According to Granger causality test methodology if $p$-value of less than 0,05 means that null hypothesis can be rejected. In the research pcalculated $<$ pcritical therefore null hypothesis can be also rejected using this test and population dynamics Granger causes GDP growth. Therefore population dynamics can be effective driver of economic development of the state being combined with other policy measures.

Results of this research are consistent with previous studies results. Correlation coefficient $\mathrm{R}=0,54$ demonstrates that population dynamics played important but not a single role in economic development in India. Granger analysis results confirm that GDP growth follows population increase.

\section{CONCLUSIONS}

During last two decades India has been showing phenomenal economic development. One of its main reasons is economic and social policy has been provided by government. Since 1990-s India has deregulated several industries, has privatized many state-owned enterprises, and contributed to foreign direct investments. The Indian middle class, that is almost a quarter of its total population amount, has been driving economic growth in India. High level of education and English-speaking population in urban areas attract foreign investments and provide fertile ground for an intensive development of the country's high-technology sector.

The novelty of the paper lies in the following. The study revealed that in 1961-2018 population dynamics (ages $15-$ 64) was associated with GDP growth (per capita) in India positively, and the level of the relationship was moderate that means there are many factors stimulating economic growth in India and population dynamics is only one of them. Within the research the Augmented Dickey-Fuller has been used to check population and GDP grow th series to identify if they are stationary and can be used for Granger causality test. It has shown that population and GDP growth series are stationary and Granger causality test can be performed to identify the causality direction of these series.

Granger causality test has shown that population dynamics Granger causes GDP growth in India. Correlation coefficient $R=0,54$ demonstrates that population dynamics played important but not a single role in economic development in India. Therefore positive population dynamics can be effective driver of economic development of the state being combined with other policy measures. India's experience could be a valuable lesson for other developing countries Ukraine included. The following studies will be focused on the other factors that influence GDP grow th in India.

\section{References:}

1. Berry, C. (2014), "The relationship between economic growth and population growth", SPERI British Political Economy Brief, vol. 7, available at: http://speri.dept.shef.ac.uk/wp-content/uploads/2018/11/Brief7-the-relationships-between-economic-growth-and-populationgrowth.pdf (Accessed 6 March 2020).

2. World Data Atlas Knoema (2019), "World development indicators", available at: https://knoema.com/ WBWDI2019Jan/world-development-indicators-wdi (Accessed 6 March 2020).

3. Tseng, W. and Cowen, D. (2005), India's and China's Recent Experience with Reform and Growth. Procyclicality of Financial Systems in Asia. Palgrave Macmillan, London, UK.

4. Das, G. (2006), "The India Model", Foreign affairs. vol. 4, available at: https://www.foreignaffairs.com/articles/asia/ 2006-07-01/india-model (Accessed 6 March 2020).
5. Amadeo, K. (2020), "India's Economy, Its Challenges, Opportunities, and Impact", The balance, available at: https://www.thebalance.com/india-s-economy-3306348 (Accessed 6 March 2020).

6. IMF News (2018), "India's Strong Economy Continues to Lead Global Growth", available at: https:// www.imf.org/en/News/Articles/2018/08/07/NA080818India-Strong-Economy-Continues-to-Lead-GlobalGrowth (Accessed 6 March 2020).

7. Summers, L. H. (2010), "India and the Global Economy", Asia Society, available at: https://asiasociety.org/india-and-global-economy (Accessed 6 March 2020).

8. Kaka, N. Kshirsagar, A. and Madgavkar, A. (2016), "India's economy: why the time for growth is now". McKinsey global institute, vol. 9, available at: https:// www.mckinsey.com/featured-insights/india/indiaseconomy-why-the-time-for-growth-is-now (Accessed 6 March 2020).

9. Wesle, E. and Peterson, F. (2017), "The Role of Population in Economic Growth", SAGE Journals, vol. 4, available at:https://journals.sagepub.com/doi/full/ 10.1177/2158244017736094 (Accessed 6 March 2020).

10. Kothare, R. (1999), "Does India's Population Growth Has A Positive Effect on Economic Growth?", Social Science, vol. 410, available at: http://pages.cs.wisc.edu/ dluu/data/ papers/rkothare99.pdf (Accessed 6 March 2020).

11. Gamble, A. (2014), Crisis Without End? The Unravelling of Western Prosperity, Red Globe Press. London, UK.

12. Piketty, T. (2014), Capital in the Twenty-First Century, The Belknap Press of Harvard University Press, Cambridge, New England, USA.

13. Atanda, A. A. Aminu, S. B. and Alimi, O. Y. (2012), "The Role of Population on Economic Growth and Development: Evidence from Developing Countries", MPRA Paper, vol. 37966, available at: https://www.researchgate.net/publication/254445324_The_role_of_population_on_economic_growth_ānd_development_evidence_from_developing_countries (Áccessed 6 March 2020).

14. Zhang, Y. and Xie, H. (2019), Interactive Relationship among Urban Expansion, Economic Development, and Population Growth since the Reform and Opening up in China: An Analysis Based on a Vector Error Correction Model", Land, available at: https://www.mdpi.com/2073445X/8/10/153 (Accessed 6 March 2020).

Стаття надійшла до редакиї 11.03.2020 p.

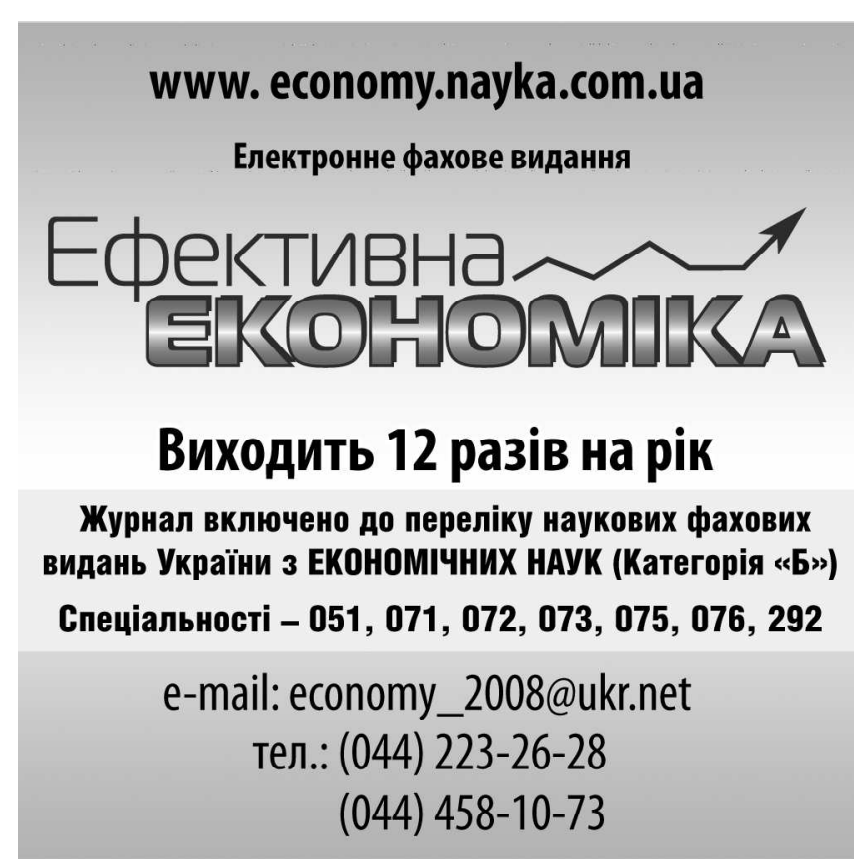

